\title{
Referate
}

Referate gelewer tydens die Afdeling Biologie van die Suid-Afrikaanse Akademie vir Wetenskap en Kuns se jaarkongres, 21-22 Junie 1994, Universiteit van die Oranje-Irystaat.

\section{Die verandering in totale opgeloste sout- konsentrasies in die Vaalrivier se water}

\author{
J.F. Prinsloo en A.J.H. Pieterse \\ Departement Plantkunde en Genetika, Universiteit van die Oranje-Vrystaat, Posbus 339, Bloemfontein, \\ 9300
}

\begin{abstract}
Versouting is 'n wêreldwye probleem en die Departement van Waterwese en Bosbou (Pretoria) het aangetoon dat die kwaliteit van die meeste waterbronne verswak as gevolg van 'n toename in totale opgeloste soute (TOS). Die vernaamste oorsake van die toename in opgelostc soute in die Vaalrivier is die terugvoer van besproeiingswater asook deur mynbouaktiwiteite in die opvangsgebied. 'n Moontlike bydraende faktor tot die hoë konsentrasies van opgeloste soute is die presipitasie van atmosferiese besoedelingskomponente waarvan sulfaat 'n groot presentasie uitmaak.

Die doel van die projek was om jaarlikse, seisoenale en ruimtelike tendense asook die ioniese samestelling van dic totale opgeloste soute in die rivier vir die studietydperk 1984 tot 1993 te bestudeer

Weeklikse gemiddelde datawaardes vanaf Balkfontein en Stilfontein is gebruik om maandelikse en jaarlikse gemiddeldes te bereken en te bestudeer.

Uit die resultate was dit duidelik dat die TOS in die Vaalrivier hoog is met'n gemiddelde jaarlikse maksimum van ongeveer $650 \mathrm{mg} \mathrm{l}^{-1} \mathrm{en}$ 'n gemiddelde minimumvan $400 \mathrm{mg} \mathrm{l}^{-1}$. Die gemiddelde TOS vir die studieperiode 1984-1993 was $520 \mathrm{mg} \mathrm{l}^{-1}$ wat ongeveer vier keer hoör
\end{abstract}

is as die wêreldgemiddeld vir rivienwater. 'n Gemiddelde toename van $25 \mathrm{mg} \mathrm{l}^{-1}$ per jaar is ook vir die studietydperk waargeneem.

Die ioniese samestelling van die totale opgeloste soute in die rivier was in die verhouding van $\mathrm{SO}_{4}{ }^{2-}>>\mathrm{Ca}^{+}$ $\geq \mathrm{Cl}^{-} \geq \mathrm{Na}^{+} \geq \mathrm{Mg}^{2+}>>\mathrm{K}^{+}$. Die hoë $\mathrm{SO}_{4}{ }^{2-}$ konsentrasie dui aan dat daar sulfaatbesoedeling in die Vaal rivier voorkom.

'n Konstante variasiepatroon in die ioonsamestelling is waargeneem wat daarop dui dat die oorsprong van die opgeloste soute van dieselfde brontipe mag wees. Duidelike seisoenale verandering. wat sterk deur reënval bcinvloed word, word ook in die TOS waargeneem. Die opgeloste soutkonsentrasic is hoër gedurende dic wintermaande en laag gedurende dic somermaande. met dic laagste gemiddelde opgeloste soutkonsentrasie wat gedurende die vloede van Maart 1988 en Februarie 1989 voorgekom het

Die hoë TOS in die Vaalrivier mag moontlike verheldering van die waterkolom tot gevolg hê. wat die onderwaterligklimaat mag verbeter en tot groter algopbloeie kan lei. Hierdie aspek van verheldering moet egter nog ondersoek word.

\section{Die invloed van flokkuleermiddels op die groei- en fotosintesetempo's van verskillende fitoplanktonsoorte uit die Vaalrivier}

\author{
D.F. Traut, R. Jordaan en A.J.H. Pieterse \\ Departement Plantkunde en Genetika, Universiteit van die Oranje-Vrystaat, Posbus 339, Bloemfontein, \\ 9300
}

Een van die belangrikste faktore wat watersuiwering versteur, is die vermoë van alge om verskillende eenheidsprosesse by watersuiwering binne te dring. Die binnedringing kan toegeskryf word aan morfologiese eienskappe, soos die vorm van selle, teenwoordigheid van flagellums en die voorkoms van uitsteeksels, of deur die fisiologiese toestand van die selle. Die fisiologiese toestand bepaal die digtheid van die selle en hulle vermoë om die invloed van inhiberende stowwe te weerstaan

Om gesuspendeerde deeltjies uit die water te verwyder, word $\mathrm{FeCl}_{3}$ as primêre koagulant gebruik, terwyl kalk. veral by sekere aanlegte in die Vaalrivier-opvanggebied, as koagulanthulpmiddel gebruik word. Die byvoeging van $\mathrm{FeCl}_{3}$ en kalk dra by tot die destabilisering van die negatief-gelaaide deeltjies by wyse van dic positiefgelaaide $\mathrm{Fe}^{3+}$ - en $\mathrm{Ca}^{2+}$-ione.

Die uitwerking van kalk by verskillende $\mathrm{pH}$-toestande en verskillende $\mathrm{FeCl}_{3}$-konsentrasies op die fisiologiese aktiwiteit van vyf verskillende algspesies (Anabaena cylindrica, Microsustis aeruginosa, Monoraphidium minutum, Cosmarium laeve en (vclotella meneghiniana) is bestudeer. Koolst ofassimilasietempo "s is gebruik om fisiologiese aktiwiteite te bepaal. Daar word aanvaar dat 
fisiologies-aktiewe selle minder dig is, en dat die uitsaktempo van sulke selle stadiger as fisiologiesonaktiewe selle sal wees. By die kalkbyvoeging vir $A$. cylindrica is ' $\mathrm{n}$ toename in koolstofassimilasie tesame met 'n toename in $\mathrm{pH}$ waargeneem. Die grootste inhibering van $\mathrm{C}$-assimilasie het plaasgevind by $\mathrm{pH} 8$. Konsentrasies van 10 tot $15 \mathrm{mg} / / \mathrm{Fe}^{3+}$ het fisiologiese aktiwiteit in die hoogste mate geïnhibeer, en kan daarom sedimentering bevorder.

By die kalkbyvoeging vir $M$. aeruginosa is 'n afname in koolstofassimilasie tesame met ' $n$ toename in $\mathrm{pH}$ vanaf $\mathrm{pH} 9$ wargeneem. Die $\mathrm{pH}$ waar die grootste inhibering van $\mathrm{C}$-assimilasie plaasgevind het, was 11 . Verhoging in $\mathrm{FeCl}_{3}$-konsentrasie bevorder die inhibering van $\mathrm{C}$-assimilasie. Die laagste koolstofassimilasie is by $20 \mathrm{mg} / \mathrm{FFe}^{3+}$ aangetref. Hoë $\mathrm{FeCl}_{3}$-toediening verlaag metaboliese aktiwiteit, en behoort dus sedimentering aan te help.

By die kalkbyvoeging vir $C$. laeve is 'n toename in koolstofassimilasie tesame met ' $n$ toename in $\mathrm{pH}$ waargeneem. Die $\mathrm{pH}$ waar $\mathrm{C}$-assimilasie in die hoogste mate geinhibeer word, is by $\mathrm{pH} 8$. Die laagste fisiologiese aktiwiteit is by $10 \mathrm{mg} / 1 \mathrm{Fe}^{3+}$ waargeneem, wat aandui dat sedimentering by dié konsentrasie bevorder kan word.

By die kalkbyvoeging vir $M$. minutum is ' $n$ afname in koolstofassimilasie tesame met 'n toename in $\mathrm{pH}$ waargeneem. Lae fisiologiese aktiwiteit by $\mathrm{pH} 11$ kon sedimentering aanhelp. By die $\mathrm{FeCl}_{3}$-behandelings het $\mathrm{Fe}^{3+}$ weinig verskil in koolstofassimilasie teweeggebring. Daar het wel inhibering van C-assimilasie by $20 \mathrm{mg} /$ $1 \mathrm{Fe}^{3+}$ plaasgevind.
By die kalkbyvoeging vir C. meneghiniana is ' $n$ toename in koolstofassimilasie tesame met 'n toename in $\mathrm{pH}$ waargeneem. Die pH waar die hoogste mate van inhibering van C-assimilasie plaasgevind het, was $\mathrm{pH} 8$. By die $\mathrm{FeCl}_{3}$-behandeling is daar ' $\mathrm{n}$ af name in koolstofassimilasie met ' $\mathrm{n}$ toename in $\mathrm{FeCl}_{3}$-konsentrasie waargeneem. Byvoeging van hoë $\mathrm{FeCl}_{3}$-konsentrasies bevorder dus sedimentering deurdat dit die fisiologiese aktiwiteit vertraag. Die behandelings is oor 'n periode van een dag uitgevoer, wat goed vergelyk met die retensietyd van die water in watersuiweringsaanlegte.

Die volgende gevolgtrekking kan uit die resultate van hierdie studie gemaak word:

By die meeste van die algspesies wat ondersoek is, het die metaboliese aktiwiteit by laer $\mathrm{pH}$-waardes afgeneem. Daar kan veronderstel word dat die selle by laer $\mathrm{pH}$ waardes digter is, en dat laer $\mathrm{pH}$-waardes sedimentering behoort aan te help. By Monoraphidium minutum en Microcystis aeruginosa is dit nie die geval nie. By hierdie twee algsoorte het ' $\mathrm{n} \mathrm{pH}$ van 11 sedimentering waarskynlik bevoordeel.

Met die $\mathrm{FeCl}_{3}$-behandeling is aangetoon dat $\mathrm{Fe}^{3+}$ klaarblyklik nie 'n groot inhiberende uitwerking op koolstofassimilasie het nie. Daar kan wel afgelei word dat hoë $\mathrm{FeCl}_{3}$-konsentrasies as 'n flokkuleermiddel gebruik kan word. In die geval van Cosmarium laeve sal $\mathrm{FeCl}_{3}$ 'n doeltreffende primêre flokkulant wees, omdat fisiologiese aktiwiteit laer as by die kontrole was. Dié selle is waarskynlik ook digter en dit sal die uitsaktempo versnel.

\title{
Limnologiese aspekte van die Loch Vaal, Vereeniging
}

\author{
A.J.H. Pieterse \\ Departement Plantkunde en Genetika, Universiteit van dieOranje- Vrystaat, Posbus 339, Bloemfontein \\ 9300
}

Die Loch Vaal verteenwoordig 'n vlak en oop watergebied wat 'n kort afstand stroomop van die sluise van die Rand Water Barrage in die Vaalrivier uitmond. Die Rietspruit vloei die Loch Vaal binne. Sedert ongeveer 1987 kom algopbloeie onder andere deur Microcystis aeruginosa, Anabaena circinalis en Oscillatoria simplicissima in die Loch Vaal voor. Hierdie opbloeie skep estetiese onaanvaarbare toestande en dra by tot onooglike opdrifsels en water wat sleg ruik en smaak. Daarbenewens kan die blougroenalge giftige verbindings vorm. Om hierdie rede stel die opbloeie gesondheidsgevare daar in 'n omgewing wat intensief vir behuising- en ontspanningsdoeleindes aangewend word. Oewerbewoners is daarom begaan oor die waarde van die eiendomme.

'n Ondersoek is vervolgens onderneem om algbiomassa en omgewingsveranderlikes met verloop van tyd te beskryf, om voedingstowwe wat alggroei beperk te identifiseer, en om navorsingsbehoeftes en bestuursopsies vir die Loch Vaal en Rietspruit voor te stel. Die doel is om uiteindelik ' $n$ toepaslike bestuursen beheerstrategie vir alggroei in die Loch Vaal te ontwikkel.
Die Loch Vaal het 'n gemiddelde diepte van 1,5 m, 'n lengte van $4,0 \mathrm{~km}$, 'n volume by volvoorraadhoogte van $2,7 \times 10^{6} \mathrm{~m}^{3}$ en 'n oppervlakte van $1,8 \mathrm{~km}^{2}$. Digte stande van Phragmites sp. kom by sekere oewersones en by die inloop van die Rietspruit voor. Rand Water, Vereeniging, moniteer toestande in Loch Vaal-water sedert 1987 ten opsigte van algbiomassa en omgewingsveranderlikes. Hierdie inligting is vir die uitvoer van die studie gebruik.

Die vlak, oop vorm van die Loch Vaal dra tot die ontwikkeling van algopbloeie by. Die water is betreklik helder, en gesuspendeerde algbiomassa verteenwoordig die hoofbron van die troebelheid in die Loch Vaal. Temperatuur en troebelheid verskil soms aansienlik by verskillende posisies. Alhoewel voedingstowwe deur die bodemsedimente aan die waterkolom gelewer mag word, verteenwoordig die invloeiende Rietspruit die vernaamste bron van voedingstowwe. Die grootste algkonsentrasie kom voor waar die Rietspruit die Loch Vaal binnevloei, en algkonsentrasies in die Loch Vaal is normaalweg veel hoër as in die Vaalrivier self. Die Loch Vaal stel derhalwe 'n bron van algmateriaal vir die Vaalrivier daar. Dit is nie duidelik hoe ver stroomaf in die Vaalrivier die algmateriaal gevoer word nie, maar 
daar is aanduidings dat dit ten minste tot by Parys mag wees.

Alggroei word klaarblyklik deur anorganiese $\mathrm{P}-\left(\mathrm{PO}_{4}-\right.$ $\mathrm{P}$;primêr-beperkend) en $\mathrm{N}$-verbindings ( $\mathrm{NO}_{3}-\mathrm{N}, \mathrm{NH}_{4}-\mathrm{N}^{+}$: sekondêr-beperkend) beheer. Retensietye in die Loch Vaal het van ongeveer 20 dae (1986/1987) tot 30 dae (vanaf 1990/1991 tot 1993) toegeneem, en Oscillatoria simplicissima het Microcystis aeruginosa as dominante algsoort, na 'n toename in $\mathrm{P} 0_{4}$-P-belading, sedert 1989/ 1990 vervang. Potensieel N-beperkende toestande heers klaarblyklik sedert 1991, toestande wat uiteindelik tot die ontstaan van Anabaena circinalis-opbloeie mag lei.

Die volgende aanbevelings ten opsigte van toekomstige navorsing kan op grond van die resultate gemaak word: Die algbevolkings moet geïdentifiseer word, die bevolkingsamestelling geanaliseer word, en die verbande daartussen en omgewingsveranderlikes bepaal word. Roetine-analise oor alggifstowwe moet gedoen word, en ondersoek moet na die bodemsedimente as bronne en valle vir voedingstowwe en algbevolkings ingestel word.
Die bodemsedimente moet ook ondersoek word om die invloed van afseëling, UV-bestraling deur sonlig, uitdroging en verhoogde temperatuur, op die voorsiening van algselle as inokulums asook voedingstowwe aan die waterkolom te bepaal. Die seisoenale invloed van makrofiete, veral Phragmites sp., op die konsentrasie van voedingstowwe in die water moet ook bepaal word.

Toekomstige algbeheerstrategieë behoort die vermindering van anorganiese $\mathrm{N}$ - en P-voorsiening aan die waterkolom in die Loch Vaal in te sluit. Verskillende opsies wat oorweeg behoort te word, is die beperking van en beheer oor diffuse- en puntbronne van voedingstowwe in die Rietspruitopvanggebied, die verwydering van fosfaat uit Rietspruitwater in 'n verwyderingsaanleg of deur Phragmites-stande, en deur die afsluiting van die bodem met behulp van chemikalieë. Verdere beheermaatreëls vir die beheer van alggroei om ondersoek te word, sluit in die invloed van baggering, die periodieke blootlegging en uitdroging van die bodem, en die verdunning en uitspoel van die water met behulp van water uit die Vaalrivier.

\title{
Fitoplanktonsuksessie en -biomassa in die middel-Vaalrivier
}

\author{
S. Janse van Vuuren \& A.J.H. Pieterse \\ Departement Plantkunde en Genetika, Universiteit van die Oranje-Vrystaat, Posbus 339, Bloemfontein, \\ 9300
}

Die Pretoria-Witwatersrand-Vereeniging (PWV) kompleks, ook bekend as die hartland van Suid-Afrika, is van die Vaalrivier afhanklik vir water vir drink-, mynbou-, industriële- en landboudoeleindes. Die totale aanvraag vir water uit die rivier neem toe. Behalwe vir die direkte gebruike word die Vaalrivier ook vir ontspanningsdoeleindes gebruik. Die Vaalrivier kan dus met reg die hardwerkendste rivier in Suid-Afrika genoem word. Die storting van industriële, mynbou- en huishoudelike afvalprodukte vind ook in die rivier plaas. Dit lei tot ' $n$ verhoging in die konsentrasie van voedingstowwe in die water wat algopbloeie tot gevolg kan hê. Die identifisering van algsoorte is belangrik omdat besondere algspesies vir besondere probleme verantwoordelik is.

Die doel van hierdie studie was om meer inligting oor die alggroepe en -spesies teenwoordig by vier versamelpunte in die Vaalrivier te verskaf.

Watermonsters is vanaf 1991 tot 1993 elke tweede week by vier punte in die middel-Vaalrivier versamel, naamlik (in 'n stroomaf volgorde) by die Randwater Barrage (naby Vanderbijlpark), Parys, Stilfontein en Balkfontein (naby Bothaville). Algspesies teenwoordig is geïdentifiseer en met standaardmetodes gekwantifiseer.

Ongeveer 124 spesies en variëteite behorende tot sewe hoofalggroepe, $\mathrm{nl}$. Cyanophyceae (blougroenalge), Bacillariophyceae (diatome), Chlorophyceae (groenalge), Cryptophyceae (kriptofiete), Chrysophyceae (gouealge), Dinophyceae (dinoflaggelate) en Euglenophyceae (euglenofiete) is gedurende die studie-tydperk geïdentifiseer. Die Chlorophyceae, gevolg deur die Euglenophyceae, het die grootste spesie-verskeidenheid getoon.
Oor die algemeen was daar nie groot verskille tussen die fitoplankton-samestelling van die vier verskillende versamelpunte nie.

By die Barrage is 'n totaal van 103 spesies geïdentifiseer. Diatome en groenalge was die dominante groepe met opbloeie van blougroenalge gedurende die middel- en laat- somermaande. Die grootste verskeidenheid van Cyanophyceae-spesies, naamlik nege, is by die Barrage-versamelpunt gevind. Verteenwoordigers van ander alggroepe was nie in hoë konsentrasies aanwesig nie, maar verteenwoordigers van die Euglenophyceae en Cryptophyceae het deur die hele studieperiode voorgekom. 'n Positiewe verband tussen die algsel- en chlorofil $\boldsymbol{a}$-konsentrasie is aangetref.

'n Totaal van 103 spesies is ook by die Parys versamelpunt geïdentifiseer. Hier was die diatome en groenalge ook die dominante groepe wat mekaar afwisselend opgevolg het. Die fitoplankton-samestelling is deur redelik lae konsentrasies van blougroenalge gekenmerk. 'n Positiewe verband tussen totale algtellings en chlorofil $a$-konsentrasie kon by Parys aangetoon word.

By Stilfontein is ' $n$ totaal van 102 spesies geïdentifiseer. Die diatome en groenalge was weereens die dominante groepe. Opbloeie van blougroenalge het tydens die somermaande voorgekom. Periodes gekenmerk deur hoë algtellings geasosieer met lae chlorofil $a$-konsentrasies kon waargeneem word. Gedurende al dié periodes was klein diatoomselle dominant. Diatome bevat redelik min chlorofil $a$ per seleenheid en opbloeie was deur baie klein selle gekenmerk. Omdat die selle so klein was, was 'n groot getal nodig om dieselfde chlorofil $a$-konsentrasie te bereik as groter selle. 
Balkfontein was die versamelpunt waar die kleinste verskeidenheid spesies, naamlik 98 , geïdentifiseer is. Soos by die ander versamelpunte was die diatome en groenalge ook hier die dominante groepe met opbloeie van blougroenalge wat gedurende die somermaande voorgekom het. Die grootste verskeidenheid Euglenophyceae-spesies sowel as Euglenophyceae-biomassa is by dié versamelpunt aangetref, waarskynlik a.g.v. hoë vlakke van besoedeling deur mangaan en organiese verbindings. Die konsentrasie van Dinophyceae was ook hoër by Balkfontein as by die ander versamelpunte.

Alhoewel die biomassa van verskillende alggroepe by die Balkfontein-versamelpunt hoër was as by die ander punte, wil dit voorkom asof die spesieverskeiden-heid vanaf die Barrage na Balkfontein (stroomaf) afgeneem het. Die verskeidenheid van Cyanophyceae-spesies het stroomaf afgeneem, terwyl sowel die spesieverskeidenheid as biomassa van die Eugleno-phyceae stroom af toegeneem het.

\title{
Fisiese, chemiese en biologiese veranderinge in die Vaalrivier by Balkfontein (1986-1993)
}

\author{
J.C. Roos en A.J.H. Pieterse \\ Departement Plantkunde en Genetika, Posbus 339, UOVS, Bloemfontein, 9300
}

Oormatige alggroei kom periodiek in die middelVaalrivier as gevolg van voedingstofverryking voor. Die onderlinge wisselwerking tussen algbevolking en omgewingsveranderlikes is bestudeer ten einde die oorsake van algopbloeie en ander verskynsels beter te begryp. Tendense van enkele omgewingsveranderlikes wat fitoplanktonbiomassa en fitoplanktonproduktiwiteit beïnvloed, word beklemtoon.

Die fotosintetiese aktiwiteit van die fitoplankton is d.m.v. die ${ }^{14} \mathrm{C}$-metode bepaal. Troebelheid, ligindringing, diepte van die eufotiese sone en chlorofil $a$ konsentrasie by Balkfontein is maandeliks d.m.v. standaardtegnieke bepaal. Weeklikse vloeidata, totale opgeloste soute en konsentrasie van voedingstowwe is van die Departement Waterwese en Bosbou, Pretoria verkry.

Die jare 1988 en 1989 is deur hoë vloei gedurende Februarie-Maart gekenmerk met gepaardgaande hoë troebelheid en hoë voedingstofkonsentrasies wat opgevolg is deur intense algopbloeie gedurende die winter-lente-periode.

Die betreklik lae troebelheid (gemiddeld $<40$ NTU) van Vaalrivierwater sedert $1990 \mathrm{kan}$ aan die algemene hoë soutkonsentrasie (gemiddeld $540 \mathrm{mg} \mathrm{l}^{-1}$ ) en moontlik aan indringing van waterhiasinte (Eichhornia crassipes) toegeskryf word. Die hiasinte tree waarskynlik as 'n biofilter op wat sedimente vasvang en voedingstowwe opneem. Die gevolglik dieper eufotiese sone was geassosieer met verhoogde fotosintetiese effektiwiteit en fotosintetiese kapasiteit, maar verlaagde produktiwiteit per eenheidsoppervlakte wat aan laer chlorofil $a$ konsentrasies toegeskryf kan word.

1986 tot 1989 is deur toenemende algbiomassa gekenmerk. 'n Stelselmatige verlaging in die gemiddelde jaarlikse produksie en chlorofil $a$-konsentrasie sedert 1989 kan hoofsaaklik aan verlaagde voedingstofbeskikbaarheid, veral silika en stikstof, toegeskryf word aangesien genoegsame onderwaterlig beskikbaar was.

Lae N:P-verhoudings $(<15)$ sedert 1991 dui daarop dat die Vaalrivier omgeskakel het van 'n fosfaat-beperkte stelsel (1986 tot 1990) na 'n potensieel stikstof-beperkte stelsel (1991 tot 1993). Die verlaging van die N:Pverhouding is veroorsaak deur aansienlik verhoogde fosfaatkonsentrasie.

Resultate van hierdie studie ondersteun 'n konseptuele model wat aantoon dat biologiese produksie die fluktuasie van sonligenergie volg maar die "klep" wat die energievloei beheer, word deur die fluktuasie van plantvoedingstowwe bepaal.

\section{Algspesies wat eenheidsprosesse by watersuiwering vermy}

\author{
R. Jordaan en A.J.H. Pieterse \\ Departement Plantkunde en Genetika, Universiteit van die Oranje-Vrystaat, Posbus 339, Bloemfontein, \\ 9300
}

Eutrofe water, soos dié van die Vaalrivier, word gekenmerk deur algopbloeie wat deur die byvoeging van voedingstowwe tot die wateromgewing veroorsaak word. Algopbloeie by punte waar water vir suiweringsdoeleindes onttrek word, veroorsaak verskeie probleme tydens die suiweringsprosesse. Die algemeenste probleem is dat die algselle die verskillende fases van suiwering vermy.

Die hoofdoel van die ondersoek na die deurdring van alge by die suiweringsaanleg by Balkfontein, is om te bepaal wat die omvang van algverwante probleme is, die 
tipes alge betrokke, sowel as die verband tussen alge in die rivierwater en alge in die verskillende fases van die suiweringsproses.

Water van die inlaat, na sekondêre sedimentasie, na sandfiltrasie, asook van die finale gesuiwerde water is vanaf Augustus 1993 tot Desember 1993 versamel. Troebelheid. chlorofil $a$ en $\mathrm{pH}$ van die verskillende versamelpunte is by die suiweringsaanleg deur middel van standaardmetodes bepaal. Algspesies is met behulp van die lig-en skandeerelektron-mikroskoop geidentifiseer, met 'n omgekeerde ligmikroskoop getel en konsentrasies bereken volgens standaardmetodes.

Nachloordosering het tussen 2,5 en $5 \mathrm{mg} / 1$, en voorchloor tussen 2 en $6 \mathrm{mg} / 1$ gewissel. Voorkalkdosering het tussen 5 en $37 \mathrm{mg} / \mathrm{l}$, en nakalkdosering tussen 0 en $18 \mathrm{mg} / 1$ gewissel. $\mathrm{FeCl}_{3}$-dosering het tussen 11 en 26 $\mathrm{mg} / 1$ en koolsuurgasdosering tussen 0 en $13 \mathrm{mg} / \mathrm{l}$ gewissel. Oor die algemeen was die chloordoserings laer as dié van die kalk-, $\mathrm{FeCl}_{3}$ - en koolsuurgasdoserings. Die voorkalkdosering was die hoogste.

Die retensietyd in die sedimenteringsdamme het min of meer konstant gebly, behalwe op Aug. 18 waar die retensietyd feitlik verdubbel het vanaf $9 \mathrm{~h}$ na $21 \mathrm{~h}$.

Verteenwoordigers van vyf verskillende alggroepe was sowel in die rivierwater as in die water wat van die verskillende suiweringsfases versamel is, teenwoordig, nl. Cyanophyceae (blougroenalge), Bacillariophyceae (diatome), Chlorophyceae (groenalge), Dinophyceae (dinofiete) en Euglenophyceae (euglenofiete).

Bacillariophyceae (diatome) was dominant in die rivierwater en is geleidelik deur die verskillende suiweringsprosesse verwyder. Die grootste hoeveelheid diatome is deur die sedimentasiefase verwyder. Die Chlorophyceae was swak verteenwoordig in die rivierwater, maar het geleidelik in verhouding vermeerder tot by die finale water waar dié groep dominant was. Die dominante groenalge was Monoraphidium arcuatum en Chlamydomonas incerta.

By die inlaat sowel as na sekondêre sedimentering en sandfiltrasie volg die chlorofil $a$ - en totale tellings nie dieselfde patroon nie. Waar die chlorofil a-konsentrasies laag was en die totale tellings hoog, was dit hoofsaaklik sentriese diatome en kleiner groenalgselle wat dominant was. Vanaf Oktober 1993 het die chlorofil $a$ - en totale tellings by sekondêre sedimentering wel dieselfde patroon gevolg en by die gefilterde water het die chlorofil $a$ - en totale tellings vanaf November 1993 dieselfde patroon gevolg.

In die rivierwater was die eensellige, skyfvormige selle (diatome) hoofsaaklik dominant. Eensellige, skyfvormige selle is geleidelik deur die verskillende suiweringsprosesse verwyder. Die grootste persentasie is deur sedimentasie verwyder. Eensellige,verlengde selle het in verhouding geleidelik vanaf die rivier na die finale water vermeerder. Vanaf Oktober tot Desember het die eensellige, sferiese selle in verhouding toegeneem vanaf die rivier tot by die finale water. Die dominante spesie was Synechococcus cedrorum, 'n blougroenalgsoort.

Die beste verwydering van algselle, gemeet aan totale tellings en chlorofil $a$-konsentrasies, het telkens by 'n hoë $\mathrm{FeCl}_{3}(3,8 \mathrm{mg} / 1)$ en 'n hoë voorkalk $(27,8 \mathrm{mg} / 1)$ dosering plaasgevind. Dus kan afgelei word dat 'n hoë $\mathrm{FeCl}_{3}$ en voorkalkdosering die beste verwydering van alge tot gevolg gehad het.

Die algspesies wat die swakste verwyder is, was Chlamydomonas incerta, Monoraphidium arcuatum, Monoraphidium circinale en Oocystis lacustris van die Chlorophyceae en Synechhococcus cedrorum van die Cyanophyceae.

Verdere navorsing moet gedoen word om te bepaal waarom hierdie besondere soorte nie doeltreffend deur die suiweringsprosesse verwyder is nie.

\title{
Die invloed van stikstof-en fosforbeskikbaarheid op die kompetisie tussen drie verskillende algspesies
}

\author{
A. Swanepoel en A.J.H. Pieterse \\ Departement Plantkunde en Genetika, Universiteit van die Oranje-Vrystaat, Posbus 339, Bloemfontein, \\ 9300
}

In die natuurlike omgewing kom 'n verskeidenheid organismes en algspesies gesamentlik voor. Hierdie toestand lei tot die ontstaan van onderlinge kompetisie tussen verskillende spesies en tussen individue van dieselfde spesie. Organismes kompeteer veral om groeiruimte, voortplantingsruimte en voedingstowwe. Kompetisie om voedingstowwe maak 'n belangrike komponent van die fitoplanktonleefwyse uit.

Aspekte van kompetisie om voedingstowwe onder kunsmatige toestande en die chemiese regulering daarvan, waar nitraat-stikstof en fosfaat-fosfor as variërende essensiële voedingstowwe gebruik is, is ondersoek. Die volgende algsoorte is by die ondersoek gebruik: Monoraphidium circinale en Chlamydomonas sp. wat albei onder die Afdeling Chlorophyta val, asook Microcystis aeruginosa wat onder die Afdeling
Cyanophyta geklassifiseer word. Volumebepalings, as 'n aanduiding van algbiomassa, is vir elke spesie afsonderlik met wiskundige formules bereken. Omdat Monoraphidium circinale so 'n groot variasie in selvorm toon, is die algemeenste vorm gebruik. Hierdie vorm maak sowat $65 \%$ van die vorme in die kultuur uit.

Monoraphidium circinale, Microcystis aeruginosa en Chlamydomonas sp. is afsonderlik in $250 \mathrm{ml}-\mathrm{sy}$ armkegelflesse vir veertien dae in die kultuurkamer by $23{ }^{\circ} \mathrm{C}$ en $60 \mathrm{E} / \mathrm{m}^{2} / \mathrm{s}$ - ligintensiteit geïnkubeer. Die medium het bestaan uit $100 \mathrm{ml}$ van die standaardvoedingsmedium, wat aanvaar word om voldoende in die voedingsbehoeftes van die fitoplankton te voorsien. Klett-lesings (wat die absorbansie van gesuspendeerde materiaal verteenwoordig), is daagliks geneem en groeikrommes is saamgestel. 
Die drie verskillende fitoplanktonspesies is vervolgens gesamentlik in die voedingsmedium geïnkubeer om onderlinge kompetisie te ondersoek.

Chlorofilbepalings is gedoen met behulp waarvan verseker is dat die aanvangskonsentrasies van elke spesie dieselfde is. Dienooreenkomstig is verskillende volumes van die moederkultuur in duplikaat na eksperimentele flesse oorgeënt en in die kultuurkamer onder dieselfde toestande as hierbo aangegee, vir veertien dae geïnkubeer.

Klett-lesings asook afsonderlike seltellings is uitgevoer. Die gemiddelde volumes van die onderskeie spesies is in berekening gebring om die volume as aanduiding van biomassa te bepaal.

Die volgende aspek van die ondersoek het dieselfde as die eerste behels, maar voedingstofvoorsiening was gerig op onderskeidelik ' $\mathrm{N} \mathrm{NO}_{3}-\mathrm{N}$ - en $\mathrm{PO}_{4}$-P-armtoestand.

Indien die algsoorte afsonderlik gekweek word, is dit duidelik dat Microcystis aeruginosa 'n langer sloerfase vertoon en dat die stasionêre fase later (dag 13 of 14) bereik word as by Chlamydomonas sp. en Monoraphidium circinale waar die stasionêre fase ongeveer teen dag 6 bereik is.

Onder normale voedingstofvoorsiening het die Chlamydomonas sp. gedomineer, terwyl Microcystis aeruginosa en Monoraphidium circinale feitlik ewe sterk na vore gekom het. Die Chlamydomonas-spesie is ook waarskynlik beter aangepas om onder fosforarmtoestande as onder stikstofarmtoestande te kompeteer. Monoraphidium circinale, aan die ander kant, blyk beter aangepas te wees om onder stikstofbeperkende toestande te groei. By Microcystis aeruginosa verskil groei nie veel onder enige van die behandelings nie. Dit blyk dat dié spesies, onder die spesifieke toestande, waarskynlik swak aangepas is om doeltreffend te kompeteer.

Groeiremming deur voedingstofbeskikbaarheid in die omgewing het volgens hierdie studie 'n verandering in spesiedominansie tot gevolg. In die fosforarmmedium het Chlamydomonas sp. dominant na vore getree, terwyl stikstofbeperking Monoraphidium circinale bevoordeel het.

Betreklik min is tot dusver nog gedoen om die fisiologiese grondslag van kompetisie tussen verskillende fitoplanktonspesies onder natuurlike toestande te ondersoek. Ondersoeke na die faktore wat kompetisie beïnloed, is van groot belang in navorsing oor faktore wat alggroei beïnvloed. Laasgenoemde mag lig werp op die redes vir dominansie en die probleme wat dit tot gevolg het.

\title{
Askospoorultrastruktuur en -ontwikkeling by die identifikasie van'n fungus geïsoleer in Taiwan
}

\author{
L. le Roux en P.W.J. van Wyk \\ Departement Plantkunde en Genetika, Universiteit van die Oranje-Vrystaat, Posbus 339, Bloemfontein, \\ 9300
}

Ceratocystis Ellis et Halsted sensu lato sluit drie genera in, nl. Ceratocystis sensu stricto, Ophiostoma H. et P. Sydow en Ceratocystiopsis Upadhyay et Kendrick, en behoort tot die Ascomycotina. Hierdie genera is verteenwoordigend van insekgeassosieerde fungi wat plantpatogene insluit, onder andere dié van bome. Tydens die isolering van die spesie in Taiwan is die ongeslagtelike fase as Sporothrix geïdentifiseer. Die Sporothrix ongeslagtelike stadium is kenmerkend van die Ophiostoma-genus van die groep organismes.

Die askospore van verskeie Ceratocystis sensu latospesies het besondere vorms. Vorige ligmikroskopiese studies het min inligting verskaf oor die struktuur en ontwikkeling van die spore. Die twyfel wat daar tans bestaan oor die ontwikkeling en evolusie van die askospore kan moontlik oorkom word deur inligting wat mag voortspruit uit ultrastrukturele studies.

Die doel van hierdie studie was om dié onbekende Ophiostoma-spesie met behulp van verskeie morfologiese kenmerke te identifiseer. Kenmerke soos peritekiumgrootte, askospoor-ontwikkeling, -vorm en -grootte is ondersoek. Lig- en elektron-mikroskopiese tegnieke is vir die ondersoek gebruik. Die doeltreffendheid daarvan is in die taksonomie van hierdie organisme bepaal. Standaardvoorbereidingsmetodes vir ultra-strukturele studies is gevolg. Sneë (60 nm dik) is met behulp van glasmesse en 'n ultramikrotoom (LKB ultratome III) gemaak en is met swaarmetaaloplossings gekleur. Die sneë is met behulp van 'n Philips EM300-deurstraalelektronmikroskoop en Jeol Winsem-aftas-elektronmikroskoop ondersoek.

Kwantitatiewe en kwalitatiewe eienskappe van die peritekium is bepaal. Daar is onder andere bepaal of ostiolêre hifes aan- of afwesig is, die nekpunt-, nekbasisen peritekiumdeursnee, en neklengte is gemeet. Die peritekiumbasiskleur is waargeneem en daar is bepaal of peritekiumornamentasie aan- of afwesig is. Hierdie resultate is volgens 'n sinoptiese sleutel verwerk.

Die sinoptiese sleutel is gebruik om die grootte van die peritekiumbasis, die neklengte, nekbasis- en nekpuntdeursneë te vergelyk. Die peritekiumbasis is dienooreenkomstig as klein geïdentifiseer en donker gekleurd, die neklengte as lank en die nekbasis- en nekpuntdeursnee as klein. Dié resultate is in 'n databasis ingevoer en met kenmerke van bekende genera en spesies vergelyk vir moontlike identifikasie. Na aanleiding hiervan kon drie moontlike spesifieke epitetons vir die isolaat daar gestel word, nl. $O$. augusticollis, $O$. denticulata en $O$. narcissi.

Die klassifikasie van die onbekende isolaat tot 'n enkele spesie het verdere ultrastrukturele studies genoodsaak. Die askospoorstruktuur en -ontwikkeling is bestudeer. Daar is bevind dat die askospoorvorm 
ellipsoïedaal is en tesame hiermee bestaan die askospoorwand uit drie lae sonder ornamentasie. Die askospoorlengte en -wydte is ook gemeet en volgens die sinoptiese sleutel verwerk en as klein geklassifiseer.

Die bykomende resultate is ook in die databasis ingevoer. Een spesie kon sodoende geïdentifiseer word waarvan die kenmerke die meeste ooreenstem met die bekende kenmerke van spesies in die databasis. Die spesie is as Ophiostoma narcissi Limber geidentifiseer. Om egter werklik sekerheid te bekom of die geisoleerde spesie wel Ophiostoma narcissi is, is dit noodsaaklik dat ' $n$ verdere vergelykende studie gedoen moet word met ' $n$ standaardkultuur vanuit een van die internasionale kultuurversamelings. Dit is egter nie tydens die studie gedoen nie. Die geisoleerde spesie kon nie op grond van basiese morfologiese kenmerke geïdentifiseer word nie. Die askospoorultrastruktuur en ontwikkeling het wel 'n bydrae gelewer om die identifikasie van Ophiostoma narcissi moontlik te maak.

\title{
Ekologiese en ekonomiese aspekte van kruidfitomassa, kruidsamestelling en boomdigtheid op wildsplase in die Noordwes-Transvaal
}

\author{
A.G. Schmidt, G.K. Theron en W. van Hoven \\ Sentrum vir Natuurlewebestuur, Universiteit van Pretoria, Pretoria, 0002
}

Daar is weinig publikasies oor ekologiese en ekonomiese aspekte van die verwantskap tussen boomdigtheid en kruidproduksie in die Transvaalse bosveld. Die doelwitte van die studie was:

- die bepaling van die effek van boomdigtheid op kruidfitomassa en -samestelling

- die evaluering van die ekonomiese lewensvatbaarheid van ontbossing op wildsplase in die gemengde bosveldgemeenskappe van die Noordwes-Transvaal. Die studie is op die plase Toulon 495 LQ, Cradock 534 LQ en Spider 535 LQ in die Ellisrasdistrik uitgevoer. Beramings van kruidfitomassa, kruidsamestelling en boomdigtheid in ontbosde en nie-ontbosde gebiede is deur middel van die vergelykendeopbrengsdroëmassagraad- en strookperseelmetode gemaak. Beramings is in April 1990 en 1991 gemaak.

In 1990 en 1991 is daar betekenisvol meer fitomassa $(P \leq 0.05)$ in die ontbosde gebiede as in die aangrensende nie-ontbosde gebiede gevind. Panicum maximum was die kruidspesie wat die meeste bygedra het tot die toename in fitomassa in die ontbosde gebiede.

\begin{abstract}
'n Betekenisvolle afname in fitomassa $(P \leq 0.05)$ het tussen 1990 en 1991 in die ontbosde en nie-ontbosde gebiede voorgekom. Die afname is waarskynlik toe te skryf aan 'n afname in die jaarlikse reënval. Die afname in fitomassa was groter in die ontbosde as in die nieontbosde gebiede weens 'n groter afname in Panicum maximum in die ontbosde gebiede. Dit blyk dus dat dié data die bevindinge bevestig dat Panicum maximum 'n voorkeur vir bedekte sub-habitatte het en dat dit geleidelik in hoeveelheid sal afneem onder sub-optimale boomdigthede.

'n Ekonomiese analise van bogenoemde bevindinge toon dat ontbossing ekonomies lewensvatbaar op wildproduksiestelsels in die Transvaalse bosveld kan wees indien:

- die toename in grasproduksie effektief deur grasvreters benut kan word;

- 'n selektiewe ontbossingsprogram gevolg word wat die verhouding tussen boomdigtheid en grasproduksie optimaliseer.
\end{abstract}

\section{Die Nylkrokodil Crocodylus niloticus in Suidelike Afrika: kwesbaar as gevolg van inteling?}

\author{
A. Jurgens, J.C. de W. Kruger en F.H. van der Bank \\ Departement Dierkunde, Randse Afrikaanse Universiteit, Aucklandpark, Johannesburg, 2006
}

\section{INLEIDING}

Die Nylkrokodil is endemies tot Afrika en Madagaskar, en word tans in die Suid-Afrikaanse Rooidataboek as 'n kwesbare spesie beskryf. Opnames het getoon dat $75 \%$ van die nagenoeg 8000 individue wat in die natuur oor is, in bewaringsgebiede in Transvaal en Natal voorkom.
Alhoewel die oorblywende diere deur plaaslike natuurbewaringswetgewing beskerm word, is hulle getalle in die natuur besig om af te neem.

Sedert die sestigerjare, en veral vanaf 1980 , word die Nylkrokodil op redelike groot skaal op verskeie plase regoor die land, hoofsaaklik in die Transvaal, Natal en Kaapprovinsie, kommersieel vir velle en vleis geteel. 
Die plaaslike krokodilbedryf kan dus in die nabye toekoms ' $n$ wesenlike bydrae lewer tot die bewaring van die krokodilspesie.

Die groot getalle jong diere wat op krokodilplase voorkom, laat egter onwillekeurig die vraag ontstaan waarom daar besluit is om 'n kwesbare status aan die betrokke spesie te verleen. Etlike ander vrae moet ook nog beantwoord word. Min inligting is byvoorbeeld bekend oor die mate van inteling wat moontlik alreeds in krokodilbevolkings in gevangeskap voorkom, en of dié krokodille sonder probleme in die natuur vrygelaat sou kon word.

Aangesien min bekend is oor die genetiese variasie in sowel natuurlike as aangehoude krokodilbevolkings in Suid-Afrika, is daar besluit om met dié studie aandag te gee aan enkele aspekte wat moontlik lig kan werp op bogenoemde vrae.

\section{MATERIAAL EN METODES}

Verskeie weefseltipes is bekom vanaf ' $n$ krokodilbevolking op 'n plaas in die Rustenburg-distrik en 'n natuurlike bevolking by St Lucia Krokodilsentrum, St Lucia.

Weefselmonsters is voorberei en met behulp van styseljel-elektroforetiese tegnieke in die laboratorium ontleed. Styseljelle is vir proteienaktiwiteit gekleur, elektroforetogramme is geïnterpreteer, en allosiem- variasies is bepaal en statisties verwerk met behulp van 'n standaardrekenaarsprogram.

\section{RESULTATE EN BESPREKING}

Een-en-vyftig proteienkoderingslokusse is eksperimenteel in die twee bevolkings waargeneem. Allosiemvariasies is egter gevind by slegs vyf van die 51 lokusse. Die Chi-kwadraatwaardes, wat effens afwyk van verwagte Hardy-Weinberg-verhoudings, kan moontlik dui op 'n mate van inteling, wat toegeskryf kan word aan faktore soos nie-ewekansige paringspatrone en die aanwending van beperkte broeimateriaal. Die resultate dui ook op 'n relatiewe lae heterosigositeit in die twee bevolkings. Dit stem egter ooreen met waardes verkry vir verskeie ander reptielbevolkings, veral in die orde Crocodilia.

\section{GEVOLGTREKKING}

Hoewel die genetiese variasie van die twee krokodilbevolkings relatief laag is, is dit op hierdie stadium nie moontlik om dit toe te skryf aan inteling as sulks nie. Vernietiging van die akwatiese habitat deur veral menslike aktiwiteite en besoedeling, hou tans ongetwyfeld 'n groter bedreiging in, en kan uiteindelik lei tot die uitsterwing van die Nylkrokodilspesie in Suidelike Afrika.

\title{
Siliaatsimbionte van klipmossels
}

\author{
L.L. van As en L. Basson \\ Departement Dierkunde en Entomologie, Posbus 339, Universiteit van die Oranje-Vrystaat, \\ Bloemfontein, 9300
}

Die familie Patellidae word deur drie genera, Helcion Montfort, 1810, Patella Linnaeus, 1758 en Cellana Adams, 1889, aan die Suid-Afrikaanse rotsagtige kus verteenwoordig. Die kus word in drie hoofstreke en verskillende getysones ingedeel. 'n Klipmosselstratifikasie kan in die streke en sones waargeneem word. Sekere klipmossels kom reg rondom die kus voor, terwyl ander slegs in sekere streke voorkom. Net so word die klipmossels in verskillende getysone aangetref, sommige spesies kom slegs in een spesifieke sone voor terwyl ander oor meer as een sone strek. Opnames gedoen op die klipmossels van McDougalsbaai (Port Nolloth), Papendorp (Olifantsriviermond), Goukamma (Knysna) en Keurboomstrand bevestig die aanwesigheid van siliate op die kieue van die klipmossels.

Die werkswyse in hierdie studie was as volg: klipmossels is vanaf die rotse verwyder, die kieue uitgedissekteer en dadelik in die veldlaboratorium vir siliate ondersoek. Nadat die siliaatsamestelling en infestasie vasgestel is, is die kieue in $10 \%$-seewaterGNF gefikseer, vir verdere verwerking in die laboratorium te Bloemfontein. Met behulp van lewende waarnemings, verskillende kleurtegnieke, lig- en skandeerelektronmikroskopie kan morfologiese en belangrike taksonomiese kenmerke van die siliate bestudeer word

Drie siliate van die filium Ciliophora is gevind, $\mathrm{nl}$. die sessiele Mantoschyphidia (Dujardin, 1841) (Peritrichida), mobiele Urceolaria Stein, 1854 (Peritrichida), en Licnophora Claparede, 1867 (Spirotrichida). Sleutelvrae wat in die studie ondersoek is, is die volgende:
- Die status van die siliate, d.w.s. is die siliate parasities of het die siliate slegs 'n simbiotiese verwantskap met die klipmossels?

- Wat is die siliaatsamestelling van die klipmossels rondom die kus in die verskillende streke en getysones?

- Wat is die besmettingsdinamika van die siliate en kom kruisbesmetting van die siliate by die verskillende klipmosselspesies voor?

- Het die verskillende klipmossels dieselfde of verskillende siliaatsimbiont-spesies?

- Het die siliate enige patologiese effek op die kieue van die klipmossels?

- Wat is die taksonomie en morfologie van die siliate? Al die klipmossels wat ondersoek is, was met die siliate besmet en deurgaans was Mantoscyphidia die dominante siliaat. Sommige klipmossels het slegs verteenwoordigers van Mantoscyphidia gehad, terwyl Urceolaria en Licnophora simpatries saam met Mantoscyphidia op ander klipmossels voorgekom het. Die assosiasie wat tussen die klipmossel en siliate bestaan, behoort te verklaar of die siliate parasities is of slegs ' $n$ meer simbiotiese verwantskap met die klipmossels het. Alhoewel letsels op die kieue van die klipmossels waargeneem is, kon geen ander tekens van skade by die klipmossels waargeneem word nie.

Ten einde vas te stel wat die bepaalde verwantskappe en evolusionêre assosiasie tussen die klipmossels en hul siliaatsimbionte behels, is die spesifieke taksonomiese status van hierdie onbekende groep simbionte 'n baie belangrike deel van hierdie studie. 


\title{
Siliaatsimbionte van Oxystele-spesies langs die Suid-Afrikaanse kus
}

\author{
A. Botha en L. Basson \\ Departement Dierkunde en Entomologie, Universiteit van die Oranje-Vrystaat, Posbus 339, \\ Bloemfontein, 9300
}

Die genus Oxystele bestaan uit vyf spesies wat endemies aan Suidelike Afrika is, nl. $O$. sinensis, $O$. tigrina, O.variegata, O. impervia en O. tabularis. Dit is van die volopste slakke op rotsagtige strande en is algemeen as tolskulpe bekend. Die vyf Oxystele-spesies bewoon verskillende sones in die tussengetygebied, maar kom simpatries voor. Die slakke wissel mekaar af in die verspreiding om die kus vanaf Alexanderbaai tot Mosambiek, maar ten minste twee slakspesies kom simpatries op 'n gegewe plek voor. Elke slak huisves twee siliaatspesies, nl. die mobiele Trichodina oxystelis en sessiele Mantoscyphidia nama n. sp. op die kieue.

Die doel van die studie was die volgende:

- Die verspreiding van die slakgasheer om die kus is bekend en daar is vasgestel of die siliate se verspreiding daarmee ooreenstem, m.a.w. of alle slakke besmet is en of dit dieselfde siliate is wat Oxystelespesies om die kus besmet. Die grootte van die slakke, invloed van die seetemperatuur en die posisie van Oxystele-spesies in die tussengetysone is in ag geneem.

- Die besmettingsintensiteitsverwantskap tussen die twee siliate is ondersoek.

- Die transmissie en lokale verspreiding van die siliate is bestudeer.

- Die morfologie van albei siliate en die beskrywing van die sessiele siliaat is verskaf.

- Om te bepaal of die siliate ' $n$ simbiotiese of parasitiese bestaan voer en skade aan die gasheerkieue aanrig.

Slakke is aan die koue weskus by McDougalsbaai, by die mond van die Olifantsrivier, en aan die warmer suidkus by Buffelsbaai en Nature's Valley versamel. Die slakke is dadelik in ' $n$ veldlaboratorium ondersoek. Die skulpe is gekraak, kieue uitgedissekteer en smere gemaak om besmettingsintensiteit te bepaal. Die smere is genommer en later met silwernitraat en protargol geïmpregneer, asook met hematoksilien gekleur om sekere selstrukture te beklemtoon. Kieuweefsel met siliate is vir morfologiese studies gefikseer, waar hoofsaaklik van die skandeerelektronmikroskoop gebruik gemaak is. Ten einde te bepaal of die siliate skade aan die gasheer verrig, is histologiese sneë van besmette kieue gemaak. Geen Oxystele-slakke is tot op hede versamel wat nie besmet is nie, maar 'n geskikte slak met niebesmette kieue moes gevind word om as kontrole te dien. Osilinus punctulatus, wat aan Oxystele verwant is, is op die eiland Goreé, aan die kus van Senegal in Wes-Afrika versamel. Hierdie slakke was nie besmet nie en kon as kontrole gebruik word.

Resultate dui op die volgende:

- Die sessiele siliaat, M. naman. sp., is vanaf O.variegata beskryf wat by McDougalsbaai versamel is.

- Al vyf Oxystele-spesies, van alle groottes om die Suid-Afrikaanse kus, is met $T$. oxystele en $M$. nama n. sp. besmet.

- Geen spesifieke besmettingsintensiteitsverhouding bestaan tussen die twee siliate nie.

- Aangesien slakke van alle groottes besmet is en hoë besmettings gereeld aangetref word, moet ' $n$ suksesvolle transmissiemetode bestaan. Die transmissieroete kon nog nie bepaal word nie.

- Die siliate voer 'n simbiotiese bestaan, want geen nekrose of enige ander patologiese skade aan die kieue kon waargeneem word nie.

Opnames is sover slegs aan die koue weskus en warmer suidkus gedoen. Vir die oorblywende deel van die studie sal opnames aan die kus van Natal en Mosambiek gedoen word om die slak/simbiont-assosiasie aan die subtropiese Ooskus te bestudeer.

\section{Ektoparasiete van intergetypoelvisse van die Suid-Afrikaanse kus}

\author{
G.J.J. Loubser en J.G. van As
}

Departement Dierkunde en Entomologie, Universiteit van die Oranje-Vrystaat, Posbus 339, Bloemfontein, 9300

Getypoelvisse kom onder baie spesiale toestande voor en is aangepas om geweldige stresvolle toestande te oorleef. Betreklik min inligting aangaande die ektoparasiete van mariene visse is bekend. Opnames is by drie verskillende lokaliteite langs die Suid-Afrikaanse kus gedoen, asook op die eiland van Goreé aan die kus van Wes-Afrika. 33 verskillende visspesies is ondersoek en hulle was veral met lede van die Mobilina en Sessilina besmet, maar daar was ook verteenwoordigers van Isopoda, Monogenea en Hirudinea.

Met die studie is probeer om die volgende vas te stel:

- Wat die spektrum van intergetypoelvisse se ektoparasiete langs die Suid-Afrikaanse kus is.

- Die voorkoms en verspreiding van die gashere en parasiete langs die kus. 
- Of sekere van die parasiete gasheerspesifisiteit vertoon.

- Bestaan daar 'n verskil tussen die voorkoms en verspreiding van die parasiete van een mariene provinsie na 'n ander?

- Kan 'n vergelyking tussen varswater-, oopsee- en intergetyparasiete getref word?

- Is aanpassings van die mariene vorme met die van varswaterparasiete vergelykbaar?

Lewende gashere is versamel waarvan die vel en kieue vir die aanwesigheid van parasiete ondersoek is. Die parasiete is verwyder en op 'n toepaslike wyse gepreserveer, waarna dit by die laboratorium vir identifikasie en beskrywings voorberei is.

\section{Resultate dui op die volgende:}

- Die Sessilina is hoofsaaklik deur lede van die genus Riboschypidia verteenwoordig, 'n sessiele siliaat met 'n kompakte kern, asook lede van die genus Ambiphrya wat 'n kenmerkende lintvormige kern het.

- Die Mobilina is onder die familie Trichodinidae geplaas en ' $n$ verskeidenheid van spesies is gevind. Die meeste spesies van die Trichodinidae het op die kieue van die visgashere voorgekom. Daar is een bekende spesie gevind wat reeds in 1958 deur Raabe as Trichodina rectuncinata beskryf is. Hierdie spesie word regoor die wêreld en ook langs ons kus op 'n verskeidenheid van gashere aangetref.

- Dit is eienaardig dat sekere mariene trigodinas hoë liggame het. In kontras hiermee het varswater ektoparasitiese vorme normaalweg meer afgeplatte liggame. Dit mag met die vashegting tussen filamente of dalk selfs hul waterbalans te doen hê, aangesien sekere gashere vir tye totaal uit die water voorkom terwyl na ander poele beweeg word. Die stres op die parasiete is enorm, maar steeds is hulle op een of ander merkwaardige wyse vir hierdie omgewingsfaktore aangepas.

- 'n Baie interessante parasiet is gedurende die studie gevind, naamlik lede van die Isopoda, wat óf op die kieue voorkom met net die agterlyf wat by die kieudeksel uitsteek, óf net op die liggaam vasgeheg is. 'n Merkwaardige aanpassing is die verskynsel waar een van die verteenwoordigers van die Isopoda in die vis se mond gaan plaasneem en letterlik sy tong vervang. Hierdie isopood bring die res van sy lewe in die plek van die vis se tong deur. Volgens vorige studies doen dit geen skade aan die vis nie, sy kondisie verswak geensins nie en hy ondervind nie probleme met voeding nie. Tydens die huidige studie is dié verskynsel by 4 spesies en in 12 individue aangetref. Die vraag kan gevra word of hierdie organismes waarlik parasities is, en of dit eerder 'n mutualistiese verhouding met die vis is. Uit die literatuur word dit eerder as laasgenoemde beskou.

- Tot dusver blyk dit dat ongeveer 13 visspesies met sessiele siliate besmet was, ongeveer 23 spesies met lede van die Mobilina en 4 spesies met Isopoda. 'n Totaal van ongeveer $80 \%$ van die gashere wat ondersoek is, was besmet. Geen vis het enige tekens van 'n swakker kondisie met die lading parasiete getoon nie en dit wil dus voorkom asof die parasiete geen opsigtelike skade veroorsaak nie. Dieselfde studie is ook aan die weskus van Afrika gedoen, op die eiland van Goreé, deel van Senegal. Dieselfde tendens is by die 6 spesies vis wat ondersoek is, gevind, waarvan drie spesies met lede van die Mobilina besmet was. Een visspesie was met Trichodina rectuncinata besmet.

\title{
Morfologiese studie van die visparasiet Lamproglena clariae Fryer, 1956 (Crustacea: Copepoda)
}

\author{
H. Marx en A. Avenant-Oldewage \\ Departement Dierkunde, Randse Afrikaanse Universiteit, Posbus 524, Aucklandpark, 2006
}

Lamproglena is 'n kosmopolitiese verteenwoordiger van die Copepoda, waarvan 28 spesies wêreldwyd en 13 spesies in Afrika voorkom. Die wyfie van Lamproglena clariae, Fryer 1956, geassosieerd met die visgasheer Clarias gariepinus, is al in Njassameer en die Nylrivier aangeteken en is onlangs in die Olifantsrivier in die Kruger Wildtuin gevind. As gevolg van hul liggeel, verlengde en onduidelike gesegmenteerde liggaamsvorm, kan hulle maklik verwar word met die kieufilamente waarop hulle parasiteer. In hierdie studie is hulle morfologie bestudeer met behulp van skandeerelektronmikroskopie en ligmikroskopie, met spesifieke verwysings na die aanhangsels.

Betreffende die morfologie: die antennules bestaan uit een podomeer en dra 'n aantal gereduseerde setae op die preaksiale kant. Die kort antennes bestaan uit drie podomere waarvan die distaalgeleë podomeer vyf klein setae dra. Rudimentêre mandibels is lateraal in die bukkale opening waargeneem. Sowel die maksilla as die maksillipede het verdikte verbindings wat respektiewelik in een en drie kloue termineer. Vier paar tweeassige sowel as 'n vyfde paar een-assige, gereduseerde swempote kom voor waarvan die eerste ' $n$ aantal klein dentikels langs die kant van die basis dra. Die furkaalrami het vier terminale, rudimentêre furkaalsetae, en 2-3 laterale setae.

Die verlengde liggaamsvorm is waarskynlik 'n direkte parasitiese aanpassing van die spesie tot sy mikrohabitat. Hoe langer die kieufilament, hoe langer groei die parasiet. Sodoende word vryheid vir swaaibewegings van die abdomen en die twee eiersakke toegelaat sodat genoegsame lug verkry kan word. 


\title{
'n Morfologiese studie van die visparasiet Lernaea cyprinacea Linnaeus, 1758 (Crustacea: Copepoda)
}

\author{
J. Robinson en A. Avenant-Oldewage \\ Departement Dierkunde, Randse Afrikaanse Universiteit, Posbus 524, Aucklandpark, 2006
}

Lernaea cyprinacea is 'n ekoparasiet op varswatervisspesies. Die wyfie penetreer die vel en vestig haar permanent onder die vis se skubbe. Alhoewel die parasiet reeds in 1758 beskryf is, is die morfologiese inligting gebaseer op ligmikroskopiese studies. Gevolglik is materiaal versamel, in $70 \%$-etanol gepreserveer, gevriesdroog en met behulp van die skandeerelektronmikroskoop bestudeer.

Die kop is rond en is duidelik sigbaar en dra vier groot uitgroeisels wat die parasiet tydens vashegting gebruik. Twee antennules word aan die lateraalkante van die labrum aangetref en elk bestaan uit vyf podomere. Die antennes bestaan uit drie podomere waarvan die terminale podomeer 'n sterk beweegbare klou besit.

Die orale opening word anterior bedek deur die bolip (labrum) en posterior deur die driehoekige onderlip. Die mandibels besit 'n breë afgeplatte basale podomeer wat in 'n lansetvormige klou eindig. Die eerste paar maksilla is ventraal van die mandibels geleë en besit een podomeer. Die tweede paar maksilla besit twee tot drie podomere wat terminaal in twee beweegbare kloue eindig. Enorme maksillipede, bestaande uit twee podomere sowel as ' $n$ terminale klou, kom voor.

Ses paar swempote kom voor, waarvan slegs vyf duidelik sigbaar is. Hierdie pote verloor hul bewegingsfunksie na vashegting en swempote een tot vier ondergaan geen verdere morfologiese verandering nie.

Die permanente vashegting van die parasiet aan die gasheer d.m.v. geïnkapsuleerde ankers, sowel as die morfologiese aanpassing van die parasietliggaam in lengte sowel as breedte, speel 'n baie belangrike rol in die doeltreffende produksie van eiers, om sodoende die voortbestaan van die visparasiet te verseker.

\section{Morfologie van die manlike geslagstelsel van Chonopeltis victori Avenant-Oldewage, 1991}

\author{
A. Avenant-Oldewage en W.J. Luus \\ Departement Dierkunde, Randse Afrikaanse Universiteit, Posbus 524, Aucklandpark, 2006
}

Die meeste morfologiese beskrywings van Chonopeltisspesies is aan die hand van ligmikroskopiese bestudering van totaalpreparate gedoen - sonder enige morfologiese beskrywing van die geslagstelsels. Die huidige studie is geloods om ' $n$ volledige beskrywing van die manlike geslagstelsel en geassosieerde strukture te gee deur gebruik te maak van histologiese seriesneë, asook skandeerelektronmikroskopie.

Die algemene liggaamsvorm van die mannetjie is soortgelyk aan die van die wyfie maar met 'n relatief langer abdomen en kenmerkende kopulatoriese strukture op die tweede, derde en vierde paar pote. Knopvormige uitsteeksels kom voor op die postero-ventrale gedeeltes van die protopodiete van die tweede paar pote. Skubbe met gekamde rande kom terminaal op laasgenoemde uitsteeksel voor. 'n Sakvormige koker, met 'n spleetvormige opening op die dorsale oppervlak, word op poot drie aangetref. 'n Penstruktuur met 'n terminale induiking of vou, kom terminaal op poot vier voor.

Die swemlobbe op poot vier is rond met lang stekelvormige setas en verskil in grootte tussen mannetjies en wyfies. Laasgenoemde is 'n aanduiding dat hierdie strukture moontlik eerder 'n funksie tydens voortplanting verrig. Pigmentvlekke kom op die abdomenlobbe voor en beskerm die testis waarskynlik teen langdurige blootstelling aan sonlig.

Die gepaarde testis vul die grootste gedeelte van die abdomenlobbe. Voorts bestaan die geslagstelsel uit twee vasa efferentia, twee vasa deferentia, twee ejakulatoriese buise geassosieerd met die prostaatkliere, 'n vesikula seminalis en genitaalatrium. Die genitaalatrium open ventraal, posterior van die vierde torakaalsegment in die genitaalopening.

Die penstruktuur op die vierde paar pote is deur vorige outeurs aangedui as 'n spermoordraginstrument. Seriesneë van mannetjie-individue van $C$. australis en C.victori in die laboratorium bestudeer, wys duidelik dat daar geen verbinding tussen die geslagstelsel en die penstruktuur bestaan nie. 'n Tweede moontlikheid wat genoem word, naamlik dat sperme deur die pen by die genitaalopening versamel word, op 'n manier soortgelyk aan die werking van pedipalpe van spinnekoppe, kan ook uitgeskakel word omdat die konfigurasie van die strukture op poot vier dit onmoontlik makk vir die pen om tot by die genitaalopening te reik. Hieruit word die afleiding gemaak dat die funksie van die penstruktuur is om die wyfie in posisie te hou tydens kopulasie. 


\title{
Die invloed van koringluisinfestering op chitinase-aktiwiteit
}

\author{
M.A.C. Nagel en A-M. Botha \\ Departement Plantkunde en Genetika, Universiteit van die Oranje-Vrystaat, Posbus 339, Bloemfontein, \\ 9300
}

Die Russiese koringluis het vanaf die suidelike dele van Rusland na Afrika versprei en in 1978 is die eerste vernietigende effek van die luis in Suid-Afrika geidentifiseer. Die Russiese koringluis is skadelik as gevolg van die direkte voeding op die blare van die koringplant, wat 'n vermindering in biomassa, stadiger groeitempo of steriliteit tot gevolg kan hê. Die teling van weerstandbiedende kultivars het dus hoë prioriteit geniet. Die eerste Triticum aestivum-lyne met weerstand (SA 1684 en SA 2199) is in 1987 by die Kleingraansentrum te Bethlehem bekend gestel. Daar bestaan 'n groot leemte in die kennis aangaande weerstandbiedendheid teen luisinfestering. Die weerstandseienskappe wat slegs in sommige kultivars tot uiting kom, hou waarskynlik verband met die sogenaamde hipersensitiewe reaksie (HR-reaksie). Alhoewel die HR-reaksie baie kompleks is, word baie metaboliese reaksies met hierdie reaksie geassosieer, soos onder andere die verhoging van selwandbiosintese, lignifisering en kalloseneerlegging. Die HR-reaksie gaan verder gepaard met die produksie van 'n aantal spesifieke proteiene, die sogenaamde patogeenverwante proteiene (PR-proteïene). Dit is algemeen bekend dat die PR-proteïene grootliks bydrae tot weerstandbiedendheid teen patogene en daar word dan ook gepoog om te bepaal of dié versameling proteïene ook 'n rol tydens plant-insek-interaksie speel.

In hierdie studie is daar hoofsaaklik na die invloed van luisinfestering op chitinase-aktiwiteit gekyk. Chitinase is 'n struktureel diverse groep ensieme wat in hulle fisiese eienskappe, ensiematiewe aktiwiteite en lokalisering in plantkompartemente verskil. Op grond van hulle struktuur kan plantchitinases in drie groepe verdeel word, naamlik klas I, II, en III. Klas I sluit die basiese chitinases in, wat 'n cis-ryke domein aan die $\mathrm{N}$ terminale kant bevat en ' $n$ molekulêre massa van tussen 28-34 kD besit. Klas II sluit die suur chitinases in. Hierdie groep kom hoofsaaklik ekstrasellulêr voor en besit molekulêre massa van tussen $27-28 \mathrm{kD}$. Terwyl
Klas III die chitinases insluit met aminosuurvolgordes wat totaal van dié in Klasse I en Il verskil, 'n molukulêre massa van $28 \mathrm{kD}$ besit en sowel intra- as ekstrasellulêr gelokaliseerd is. Chitinases kataliseer die hidrolise van chitien, deurdat dit die die B-1,4-bindings van Dglukoamiene afbreek om glukose- $\mathrm{N}$-asetiel (GlcNAc)eenhede te vorm. Die fisiologiese rol van die ensiem in plante is nog onbekend. Inderdaad is dit moeilik om 'n algemene funksie aan die ensiem toe te skryf, aangesien die substraat (chitien) nie in plante teenwoordig is nie. Dit vorm wel 'n strukturele komponent van die selwande van fungi en eksoskelet van intervertebrata.

Sommige verdedigingsreaksies kan geïnduseer word deur spesifieke komponente van die selwande wat tydens infestering vrygestel word. Hierdie "elisitor" -molekules kan onder andere $\beta$-glukane of lipiede wees. 'n Tweede groep molekules wat as "elisitor" kan optree, is etileen en absisiensuur. Dit is bekend dat plante na verwonding 'n verhoging in etileenproduksie toon. 'n Hipotese het dus ontstaan dat endogene etileen moontlik 'n sein vir die aktivering van verdedigingsreaksie in plante is. Die presiese werking is nog nie bekend nie, maar daar word gepostuleer dat chitinase op die selwande inwerk om die Glc-eenhede te vorm, wat weer tot 'n verhoging in etileenproduksie kan lei. Hierdie postulaat is dan in die studie getoets.

Intra- en ekstrasellulêre chitinase-aktiwiteit is spektrofotometries bepaal, terwyl die etileenproduksie met behulp van ' $n$ gaschromatograaf ondersoek is. Daar is bevind dat ekstrasellulêre chitinase-aktiwiteit slegs by weerstandbiedende plante na infestering geinduseer word en dus slegs tot die HR-reaksie beperk is. Intrasellulêre chitinase-aktiwiteit is egter ook in kontroleplante geïnduseer en hou dus ook met normale groei- en ontwikkelingsprosesse verband. Etileen veroorsaak 'n induksie van chitinase-aktiwiteit by die weerstandbiedende en vatbare plante en kan dus ' $n$ rol in plantverdediging speel.

\section{Aktiwiteite van koringapoplasensieme en die Russiese koringluisweerstandsverskynsel}

\author{
A.J. van der Westhuizen, X-M. Qian, A-M. Botha en J.G.C. Small \\ Departement Plantkunde en Genetika, Universiteit van die Oranje-Vrystaat, Bloemfontein, 9300
}

Die Russiese koringluis (Diuraphis noxia) word wêreldwyd as een van die dodelikste insekpeste van koring beskou. Die afgelope jare het dit vinnig na groot dele van die wêreld, insluitende Suid-Afrika, versprei. Die uitwerking van $D$. noxia-infestering is uniek, aangesien dit vir die meeste koringkultivars wat kommersieel verbou word, dodelik is. Die daarstelling van weerstandbiedende koringkultivars word as die enigste gangbare oplossing vir die probleem beskou. Die Kleingraansentrum te Bethlehem was die eerste in die wêreld om weerstandbiedende koringkultivars vir kommersiële verbouing vry te stel. Hierdie kultivars beskik oor 'n 
genetiese weerstandsagtergrond (DN-1) afkomstig uit Iran. Alhoewel die weerstand hoofsaaklik as 'n vorm van antibiose beskou word, is die werklike biochemiese aard daarvan onbekend. Daar bestaan oor die algemeen 'n gebrek aan kennis oor die verdedigingsreaksies van plante teen plantluise. 'n Beter begrip van die biochemiese verdedigingsmeganismes kan bydra om biochemiese merkers en geen(e) van weerstandbiedendheid, wat teelprosedures aansienlik kan bespoedig, op te spoor. Met die oog hierop het hierdie studie dus ten doel om inligting in te win oor die weerstandsmeganisme van koring teen $D$. noxia.

In 'n vorige studie is unieke apoplasproteiene in weerstandbiedende koringkultivars na $D$. noxiainfestering geïdentifiseer. Sommige van hierdie proteïne was serologies verwant aan tabak-en gars-PR-proteiene met glukanase- en chitinase-aktiwiteite. Dit is 'n aanduiding dat hierdie proteiene moontlik by die verdedigingsreaksies van koring teen $D$.noxia betrokke is. Die feit dat baie verdedigingsreaksies in die apoplas ontlok word en dat verdedigingsverwante proteiene vervolgens in die apoplas versamel, dien ter ondersteuning hiervan. In hierdie ondersoek wou ons bepaal of die versameling van infesteringsverwante apoplasproteiene in weerstandbiedende koring moontlik ook met verhoogde chitinase-, 1,3-ß-glukanase- en peroksidase-aktiwiteit, soos wat dikwels die geval by patogenese is, gepaardgaan. Die aktiwiteite van hierdie ensieme is oor 'n sekere tydsperiode in die intersellulêre wasvloeistowwe van drie weerstandbiedende (Tugela DN, Molopo DN en Betta DN) en feitlik isogeniese vatbare koringkultivars (Tugela, Molopo en Betta) onder infesterings- en nie-infesteringstoestande bepaal. Intersellulêre wasvloeistowwe is deur vakuuminfiltrasie van blare met 'n geskikte buffer en daaropvolgende sentrifugering versamel. Serologiese ondersoeke is met behulp van die Western-kladmetode en teenliggaampies van grondboontjieperoksidase, tabak-chitinase en -1,3B-glukanase gedoen.. SDS-PAGE is gebruik om die proteiene te skei.

Infestering het 'n drastiese toename in peroksidase1,3-ß-glukanase- en chitinase-aktiwiteit slegs by weerstandbiedende kultivars geïnduseer. Hierdie aktiwiteite het na infestering, na gelang van die kultivar, vir bepaalde tydsperiodes toegeneem. Die aktiwiteie van al drie ensieme was die hoogste by Tugela DN, wat ook die beste weerstandbiedendheid vertoon het. Dit is ook serologies aangetoon dat die verhoogde aktiwiteite aan die de novo-sintese van hierdie ensieme toegeskryf kan word. Sterker uiting van die betrokke gene word dus slegs by weerstandbiedende kultivars deur luisinfestering geinduseer.

Weerstandbiedende kultivars se respons op luisinfestering toon dus ooreenkomste met verdediging teen patogene. Patogeenbestandheid gaan dikwels met toenames in peroksidase-, 1,3-B-glukanase-en chitinaseaktiwiteite gepaard. Alhoewel die rol wat hierdie ensieme by die verdediging teen insekte speel, onbekend is, is dit duidelik dat die moontlike verdedigingsrespons by uitstek in weerstandbiedende koringkultivars geïnduseer word. Die verhoogde aktiwiteite van die betrokke ensieme kan ook as biochemiese merkers van weerstand dien.

\title{
Diuraphis noxia - infesteringsverwante apoplasproteïene in koring en die verband met PR-proteiene
}

\author{
A.J. van der Westhuizen en Z. Pretorius \\ Departement Plantkunde en Genetika, Universiteit van die Oranje-Vrystaat, Posbus 339, Bloemfontein, \\ 9300
}

Die Russiese koringluis (Diuraphis noxia) is 'n ernstige plaag van koring in Suid-Afrika sedert 1978. Dit hou aansienlike finansiële implikasies vir die koringbedryf in omdat $D$. noxia, in teenstelling met ander plantluise, dodelik vir plaaslik verboude koringkultivars is. Die gebruik van insekdoders is duur en skadelik vir die agroomgewing. Om hierdie probleem te oorkom, het die Kleingraansentrum te Bethlehem 'n intensiewe teelprogram aan die gang om weerstandbiedende koringkultivars daar te stel. Die afgelope twee jaar is die eerste twee Suid-Afrikaanse weerstandbiedende koringkultivars vrygestel. Die moontlikheid dat $D$. noxiabiotipes bestandheid teen hierdie weerstand kan ontwikkel, skep 'n behoefte aan korter teelprosedures. Die gebruik van biochemiese weerstandsmerkers vir siftingsdoeleindes kan aansienlik tyd spaar. Vir die opsporing van hierdie merkers, asook om uiteindelik die bestandheidsgeen(e) te identifiseer, is 'n grondige kennis van die weerstandsmeganisme belangrik. Die doel van hierdie studie is dus om inligting in te win oor die weerstandsmeganisme van koring teen $D$. noxia en die daarmee gepaardgaande opsporing van biochemiese weerstandsmerkers.

Die apoplas word as dié plek beskou waar verdedigingsreaksies ontlok word en waar baie verdedigingsverwante produkte, soos onder andere die bekende patogeneseverwante (PR-) proteiene, versamel. Stiletpenetrasie deur $D$. noxia geskied hoofsaaklik intersellulêr, d.w.s. in die apoplas. Met hierdie feite in gedagte is ' $n$ vergelykende studie van die apoplasvloeistofproteïensamestelling van drie weerstandbiedende (Tugela DN, Molopo DN en Betta DN) en feitlik isogeniese vatbare koringkultivars (Tugela, Molopo en Betta) onder infesterings- en nie-infesteringstoestande geloods. Polipeptiedprofiele van proteiene in die intersellulêre wasvloeistof, versamel deur vakuuminfiltrasie van blare met 'n geskikte buffer en sentrifugering, is met behulp van SDS-PAGE verkry. Die Western-kladmetode is gebruik om serologies die verband tussen infesteringsverwante proteïene en bekende PRproteiene uit tabak en gars te bepaal. 
In afwesigheid van luisinfestering kon geen verskille tussen die apoplasproteiensamestelling van die individuele weerstandbiedende en die ooreenstemmende vatbare kultivars aangetoon word nie. Luisinfestering het egter die akkumulering van spesifieke, maar ooreenstemmende apoplasproteiene, by die drie verskillende weerstandbiedende koringkultivars geinduseer. Die infesteringsverwante proteiene was intrasellulêr swak verteenwoordig. Hulle kon in vier molekulêremassagebiede $(28-33 ; 22-24 ; 18,5-19,5$ en $15,5-17$ kD) gegroepeer word. Daar bestaan baie ooreenstemming met die molekulêre massas van bekende PRproteiengroepe. Polipeptiede in die 28-33 kD-gebied was serologies verwant aan tabak-PR-2-proteiene (1,3B-glukanases) sowel as gars-chitinase T. Daarenteen was polipeptiede in die 22-24 kD-gebied serologies verwant aan tabak-PR-Q-proteïen (chitinase) en tabakPR-S-proteien.

Die feit dat die akkumulering van soortgelyke apoplasproteiene by drie verskillende weerstandbiedende koringkultivars, wat geneties slegs ten opsigte van hul weerstandsagtergrond ooreenstem, geinduseer word. dui op hul betrokkenheid by die weerstandsmeganisme teen die Russiese koringluis. Die serologiese verwantskap met bekende PR-proteïene is ' $n$ verdere aanduiding hiervan, asook van ooreenkomste met verdediging teen patogene. Die resultate dui ook op die afwesigheid van 'n konstitutiewe weerstandsfaktor en dat die verdedigingsrespons deur luisinfestering geïnduseer word. Infesteringsverwante proteïene kan as biochemiese merkers van weerstandbiedendheid dien.

\title{
Molekulêre merkers vir weerstandbiedendheid in koring
}

\author{
A.A. Myburgh en A-M. Botha \\ Departement Plantkunde en Genetika, Universiteit van die Oranje-Vrystaat, Posbus 339, Bloemfontein, \\ 9300
}

Triticum aestivum is 'n heksaploïed met 'n somatiese chromosoomgetal van 42 en is saamgestel vanuit 3 voorheen diploïede genome, 'n A-, B- en D-genoom, elk met 'n basiese chromosoomgetal van 7. Die genoomsamestelling is dus AABBDD. Die drie genome is afkomstig van drie naverwante, grasagtige voorouers. Die A-genoom is van Triticum urartu afkomstig, terwyl die D-genoom van Aegilops squarrosa (ook bekend as Triticum tauschii) afkomstig is. Koring is 'n allopoliploïed. Dit beteken dat die drie genome genoeg verskil dat die indiwiduele chromosome slegs met die homoloë chromosoom van dieselfde genoom tydens meiose paar om bivalente te vorm. Min variasie is egter gevind tussen die drie homoloë genome. Hulle het feitlik identiese geenvolgordes behalwe vir 4 groot chromosomale herrangskikkings. Genetiese buffering word verskaf deur die feit dat daar drie stelle genetiese inligting in die genoom vervat is. Verlies of byvoeging van chromosome het dus nie so 'n letale effek as in 'n diploïede spesie nie. Die triplisering van die genetiese inligting maak dikwels genetiese analise van koring baie kompleks. Die haploïede DNA-inhoud van koring is sowat 16 biljoen bp. Dit is dus ongeveer vyf keer die grootte van die menslike genoom. Daarby bestaan 'n groot gedeelte van die genoom uit niekoderende herhalende DNA-volgordes. Een van die grootste komponente van ons navorsing oor die weerstandsmeganisme in koring is die daarstelling van molekulêre merkers vir die verskillende koringkultivars in die studie, sowel as vir die weerstandsgene in die weerstandbiedende koringlyne.

In die studie is daar van die polimerasekettingreaksie (PCR-reaksie) gebruik gemaak en onwillekeurige geamplifiseerde polimorfiese DNA (RAPD)-produkte is verkry. Die tegniek is aangewend aangesien die afwesigheid van 'n herkenningspunt vir die 10-basispaarpriemstuk op die templaat tot gevolg sal hê dat die betrokke DNA-fragment nie gamplifiseer word nie en dus afwesig is op die jel. 'n Verandering in die lengte van die templaat tussen die herkenningspunte, soos by voorbeeld deur 'n delesie, sal ook tot 'n polimorfisme aanleiding gee. In koring word die RAPD-fragmente vanuit die hele genoom (DNA van 42 chromosome), geamplifiseer. Die bandpatrone wat so verkry word, kan gebruik word om tussen verskillende koringkultivars te onderskei. Spesifieke RAPD-fragmente wat slegs voorkom in weerstandbiedende plante en gekoppel kan word aan weerstandbiedendheid, lewer molekulêre merkers vir weerstandbiedendheid. Die aanname is dat so 'n fragment geamplifiseer word vanaf dieselfde chromosoom as die weerstandsgene.

Verskeie vatbare kultivars is in die studie ingesluit, onder andere Palmiet, Gamtoos, Kiewiet, Tugela, Betta en Molopo. Verskeie weerstandsbronne is ook in die studie ingesluit, onder andere SA 1684, SA 2199, SA 463, PI 372129, AUS 22498 en Corwa. Die resultate van die RAPD-analises op koring wat in die studie bevind is, kan as volg saamgevat word: In die studie is daar sover ongeveer 95 DNA-fragmente geproduseer deur van nege verskillende priemstukke gebruik te maak. Die nege priemstukke is uit 'n groot aantal verskillende priemstukke geselekteer. Die getal geamplifiseerde fragmente wat met die priemstukke op agarose jelle verkry is, het gewissel van 6 tot 16, met 'n gemiddeld van 10,6 fragmente per priemstuk. Die grootte van die geamplifiseerde fragmente het gewissel van $\pm 200 \mathrm{bp}$ tot $2500 \mathrm{bp}$. Van die 95 DNA-fragmente het $68 \%$ deurlopend by alle kultivars voorgekom en kon dus nie gebruik word om te onderskei tussen kultivars nie. Die oorblywende fragmente was almal polimorfies en het nie by alle kultivars voorgekom nie, of was uniek tot sekere kultivars. Slegs sowat $6 \%$ van die fragmente het herhaalbare verskille gelewer wat gebruik kan word as potensiële weerstandsmerkers. Resultate is ook deur middel van ureum-poliakrielamied gelelektroforetiese skeidings verkry en daar is bevind dat die tegniek ook geskik is vir die identifikasie van naverwante weerstandsbronne. 